Muhammed Ernur Akıner*

Akdeniz University, Vocational School of Technical Sciences, Environmental Protection and Control, Antalya, Turkey
Scientific paper

ISSN 0351-9465, E-ISSN 2466-2585

UDC: $330.12: 631.6 .02: 631.92$

doi: $10.5937 /$ zasmat2004313E

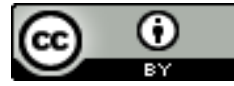

Zastita Materijala 61 (4)

$313-327(2020)$

\title{
Case study of extracting soil and land use maps to determine agricultural best management practices that can be applied to prevent erosion and fertile soil loss
}

\begin{abstract}
The Büyük Melen river in the Melen Basin meets Istanbul's drinking water needs. Protecting the basin against nutrient pollution is vital in this regard as well. This study focuses on the best possible management practice (BMPs) in the Melen Basin to reduce the export of nutrients from the agricultural areas. A region comprising industrial, farming, and residential zones is the Melen basin. There is a forecast of global climate change in Turkey, and scientists and also governors must know which areas are no longer farming zones and which will be more appropriate for agriculture. Turkey's territory is a high-risk desertification area. In Melen Basin, the soil type and land use properties have been determined and mapped using GIS and Soil and Water Assessment Tool (SWAT). Buffer BMP filter strips can be used effectively for nutrient protection that can be carried from residential areas and motorways by runoff. The region in the basin is steep, and its clay and sandy soil structures are ideal for parallel terraces, grade stabilization, strip, and contour cultivation. Unless the ground can not retain or store water, the soil can undergo sudden floods, causing an erosion of the soil's productive surface layer. When we protect the land, this condition is reduced. The land type and land use mapping should be drawn up as soon as possible for the remaining Turkish basins by scientific methods. This research is intended to be an illustration for researches on other agricultural basins in Turkey and the world for this reason.
\end{abstract}

Keywords: Agricultural best management practices, erosion, land use, Melen Basin, nutrients, soil type.

\section{INTRODUCTION}

The Melen Basin is home to two main rivers. They are the rivers of Büyük Melen and Küçük Melen (See Fig. 1). State hydraulics work (DSI) installed a water regulator near the Büyük Melen River outlet. A $150 \mathrm{~km}$ pipe is used for pumping freshwater into Istanbul [1]. Protecting the quality of water is also vital in Istanbul's potable water quality in the Melen Basin. Previous work to identify potential sources of contamination is essential for the safety of water supplies. The transportation and management policies for nonpoint emission sources and land use should be studied, most notably. This work is focused on the possible Best Management Practices for the Melen Basin to decrease nutrient export from agricultural areas.

\footnotetext{
${ }^{*}$ Corresponding author: Muhammed Ernur Akıner E-mail: Ernurakiner@gmail.com

Paper received: 20. 08. 2020.

Paper accepted: 23. 09. 2020.

Paper is available on the website: www.idk.org.rs/journal
}

\section{METHODOLOGY}

Novotny and Olem [2] note that best management practices (BMPs) entail methods that reduce nonpoint sources of pollution until the permissible rates of pollution as specified in water quality standards are reached. The BMPs should be created by research and experience. According to Novotny and Olem [2], guidance is required alongside realistic preventive measures. In addition to the vague individual definitions of what is expected, there is a desire for best practice. BMPs are used to regulate or limit the transfer through soil and groundwater of crop contaminants. Both environmental, chemical, and biological factors influencing the discipline should be taken into account when determining a BMP. Many BMPs are compatible with securing both surface and land water bodies. Many other BMPs preserve one tool at another's expense. Beyond the features of the farm's physical and management operations, the preference of BMPs always relies on the goals and objectives of those concerned [3]. 


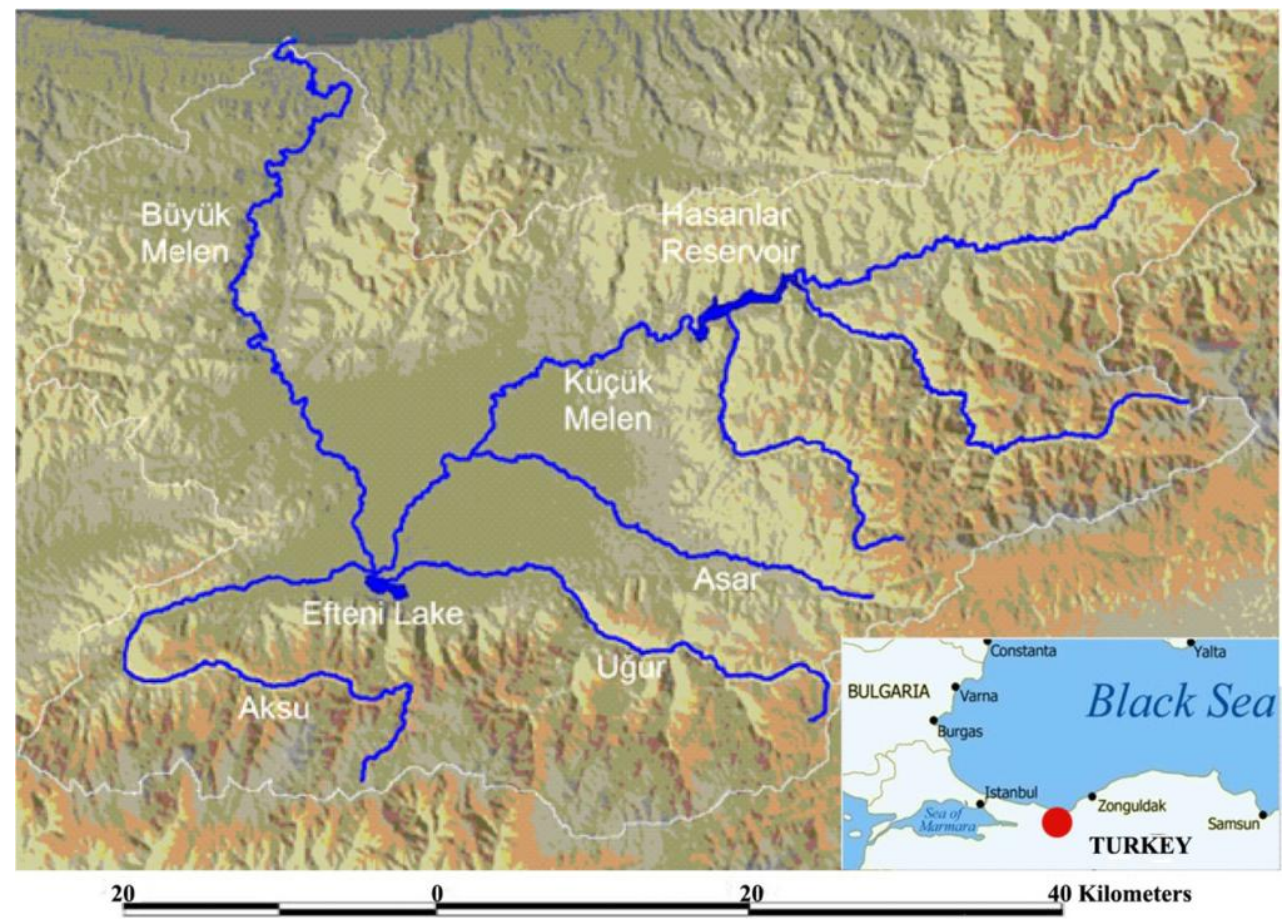

Figure 1. The Basin and its Rivers

\section{Slika 1. Sliv i njegove reke}

The most widely recognized BMP's include the buffer filter strips, contour and strip cropping, grade stabilization, grassed channels, parallel terraces, and waste management. The use of statistical models is a valuable method for the estimation of BMP's long-term results. Several studies have discussed the role of BMPs in sediment and nutrient yield reduction [4-8]. A variety of basin and field-scale models were employed to calculate BMP performance $[9,10]$. Through model WEPP, Kalin and Hantush [11] were able to simulate various BMPs, including farming activities (tillage, contouring, irrigation, runoff, field rotation), swamps, terraces, sediments, and filter fences.

\subsection{Best management practices}

Conservation tillage ensures at least $30 \%$ of the soil surface is supported by crop residue to prevent soil degradation by water [12]. For each 9 to 16 percent rise, researchers have recorded reductions of up to $50 \%$ on the volume of crop residue [13], which means that for a minimum residue coverage (e.g., 30 percent), up to 90 percent erosion rate reductions are possible. Any BMPs used to improve the efficiency of surface water can, however, accelerate transport into groundwater for contaminants [14]. The effect of tillage management on soil quality is uncertain, according to Cho et al. [15]. Besides, numerous researchers indicated that no-till activity had negative consequences with the rising leaching of pesticides into groundwater [16].
Ridge tillage, strip tillage, slit tillage, and management of seasonal residues refer to the different approaches used to manage the field along the rows while removing intrusion of crop residues between rows. During the time between harvest and plantation, waste is kept on the field for seasonal residue control. Many residues are tilled only before the crop.

Contour plowing is a useful erosion prevention tool on medium- to moderate-slope soils to farm, plant, and grow soils in outlines for agriculture [17]. Contouring also enhances infiltration and decreases the runoff surface [3]. Contour agriculture protects the water reception through the conservation of the soil resources, which are also crucial to crop production.

The planting of the form of the contour involves the planting of the cultivation of plants in strips around the field contours. The strips vary between crops grown in near provenance, for example, grains and row crops. The cultivation of field strips is defined as the growth of plants on strips lined perpendicular to the natural area slope [17]. In situations where sediment is the primary pollutants, contour and field strip cultivation is most effective. Strip cultivation is typically used in areas that have field slopes too steep to use contour cultivation.

The buffer zone or the drain line was planted as well as natural vegetation bands situated between the source of contaminants and collecting 
water to extract pollution from the river [18]. The vegetative filter strip is a BMP for extracting soil and fecal bacteria from the manured field and pasture and reducing the volume of pollutants from the ground [19]. Equation 1 is used to measure water, mineral, and pesticide trapping capacity of the filter strip [20]:

$$
\operatorname{Trap}_{\text {ef }}=0 \backslash 3 \backslash 67 \times\left(\text { Width }_{\text {filterstrip }}\right){ }^{0,42 \backslash 9 \backslash 6 \backslash 7}
$$

The width of the filter strip is Trapef $_{\text {ef }}$ where the constituent load is the fraction trapped by the filter strip and Width filterstrip $_{\text {(m) }}$.

There are three areas of an ideal riparian buffer. At the waterline begins the first zone. There are primarily trees and shrubs in this region. The first field will remain mostly intact, and animals from this region will be omitted. The other field consists of limited timber harvesting or biomass processing of nutrients obtained from the tampon. In the third region, the strip of grass filters aims at distributing flow through the first two areas to facilitate a more uniform flow.

Haycock and Pinay [21] also indicated that the riparian buffer biomass enhances nitrate preservation in the cold season. To inspect the fatality and transportability of $\mathrm{NO}_{3}-\mathrm{N}$ to the agricultural basin by way of a contour strip, and a riparian tampon strip plants with perennial vegetation including switchgrass, Sahu,and Gu [22] used the soil and water assessment tool (SWAT) for the Walnut Creek Basin, Ames, lowa. According to Sahu and $\mathrm{Gu}$ [22], several strips of perennial veggies will be much more active around the contour rather than having a riparian buffer line. For their simulations, strips sizes of $10 \%$ to $50 \%$ of the subsurface region were taken into consideration. The filter strip size influences the $\mathrm{NO}_{3}-\mathrm{N}$ discharge [22]. But Sahu and $\mathrm{Gu}$ [22] noted that the decline rate of $\mathrm{NO}_{3}-\mathrm{N}$ was lower as the band's size ranged from 30 to $50 \%$. In the case of contour bands, the utility of filter bands with 10 to 20 percent of the area was demonstrated while the use of filter bands with 10-30 percent of the area was still considered to be useful for buffer bands [22]. Results of the SWAT operation on hillslopes in the Walnut Creek Basin, Ames, lowa, showed that a filter strip with an interim covering of $10-50 \%$ of the subbasin could theoretically limit $\mathrm{NO}_{3}-\mathrm{N}$ outflows by $55 \%-90 \%$ in a medium rainfall period in the subbasin [22].

Cover crops are production and non-structural activity for the removal of sources. These crops are classified as crops cultivated while from harvest to primary crop cultivation. The principal purpose of plants is to protect the soil. The cover plants also constitute nutrients trapped in the winter and is a supply of manure in the spring [23].

\subsection{Nutrient management}

The management of nutrients is characterized as maximizing applications of plant nutrients. This optimization is intended to improve crop returns while minimizing nutrient losses on resources in surface and groundwater. The ultimate goal is to verify that there are reasonable nutrients available to meet the harvesting requirements and reduce potential environmental losses. In the case of application of manure in the autumn or winter, a large proportion of the mineral nitrogen available is lost in leaching or denitrification [24]. A standard method of using split-apply nitrogen is to add a fraction of the total amount of nutrients that must be planted before or after planting. The rest of the nutrients are used at the required rates for the expected crop returns in the growing season. In most soils, the liquidation of phosphorus is slow. The land is like a phosphate banking structure [25, 26]. Contributions are applications for fertilizer and organic manure; withdrawals are nonconsumptions of the harvested section of the crop; thus, the balance of the farm, the soil state of the soil, would remain constant if the application of the fertilizer and green manure equals off-takes of the harvested portion of the field [27]. This approach to assessing the concentrations of phosphorus fertilizer avoids undesirably high amounts of phosphorus from accumulating over many years in the soil [25].

\subsubsection{Terraces, vegetated waterways, and diversions}

Sustainable terrace practices, vegetation wetlands, and diversions are well-known BMPs. The transport of pollutants through terraces inhibits, while the flow of toxins is allowed to a lesser degree through grassy wetlands and recreation practices. Terraces are quite efficient in minimizing emissions of surface runoff from nonpoint sources [27].

Flow diversion (FDT) terraces have been extensively deployed as a valid BMP in Canada with well-documented effects at field levels [28]. Yang et al. [28] analyzed the seasonal and annual impacts of FDT for water quality in the Black Brook Basin (BBW) in the Canadian northwest and recorded that FDT applied BBW was contributing to a 56 percent decline in sediment yields. The FDT as a BMP system has also shown that not only has reduced the sediment load in the basin, but also decreased water return in the summer season as well, and managed to cut water returns by 20 percent [28]. 


\subsubsection{Sediment detention structures}

Trapping and collecting sediment is the purpose of sediment detention structures $[29,30]$. Generally, there are large sediment storage basins that capture water from a relatively wide area. The same approach is used for trapping coarse sediments through smaller systems such as control dams.

\subsubsection{Constructed wetlands}

Agricultural, municipal and industrial waste was also processed by built-in wetlands [31]. Filtration of wetlands was recognized as one of BMP to improve the quality of surface water.

\subsubsection{Stream fencing}

Stream fencing is characterized as a barrier structure that keeps cattle out from direct access to streams along stream corridors through a wire or electric fence.

\subsubsection{Rotational grazing}

Pasture rotation is a managerial and structural component source reduction practice. This research focuses on the soil, minerals, and biological waste generated by the high number of animals on land. The acceptable amount of chemical fertilizer available in animal manures is usually not necessarily determined by the nitrogen present [24]. On the other hand, in livestock manures, farmers did not take phosphorus sufficiently into account. That way, extra organic fertilizers can be substantially reduced or removed, and an unfavorably elevated amount of phosphorus in soil can also be avoided [32].

\section{RESULTS}

This research focuses mainly on the contribution of different types of soil. The effects of land use and agricultural BMPs on water quality of rivers were expected after calibration of the SWAT System for the Melen Basin, along with load estimates. But, unlike most hydraulic models, the SWAT System needs a large amount of input data. Essential data include topographical information as a digital elevation chart, a land-use chart, agricultural activity data, weather data, temperature and wind data, local radiation data, point location data, and point source discharge characteristics, and artificially managed river management information. While comprehensive data are being used, the majority of the need for spatial and temporal interpolation still poses a high degree of input uncertainty [33]. The concentrations or loads of the basin outlet can only be calculated according to the type of land use.

\subsection{GIS for data preparation}

GIS is also a useful and essential method for hydrological basin-scale research and modeling in terms of their integrative capability. GIS allows spatial and non-spatial data convergence for input models and simulation of graphical outputs efficiently. The topography for the Melen Basin was described by a Digital Elevation Model (DEM) defining the elevation of any point at a particular spatial resolution in a specific area. A DEM of $10 \mathrm{~m}$ x 10 m resolution (Fig. 2, 3, and 4) was designed for all the modified vectors.

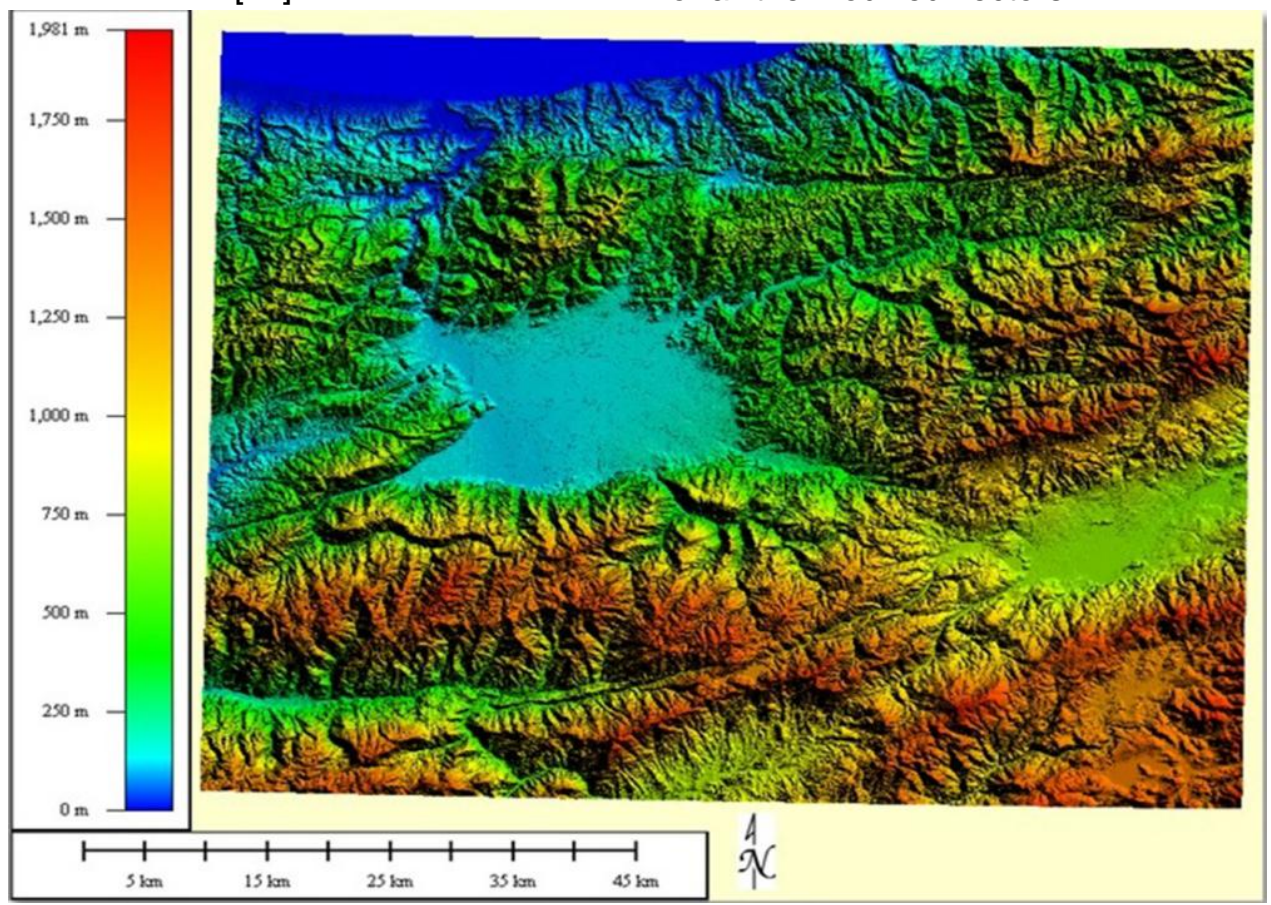

Figure 2. DEM generated from contour lines is ten meters of grid distance

Slika 2. DEM generisan iz konturnih linija sa deset metara udaljenosti mreže 


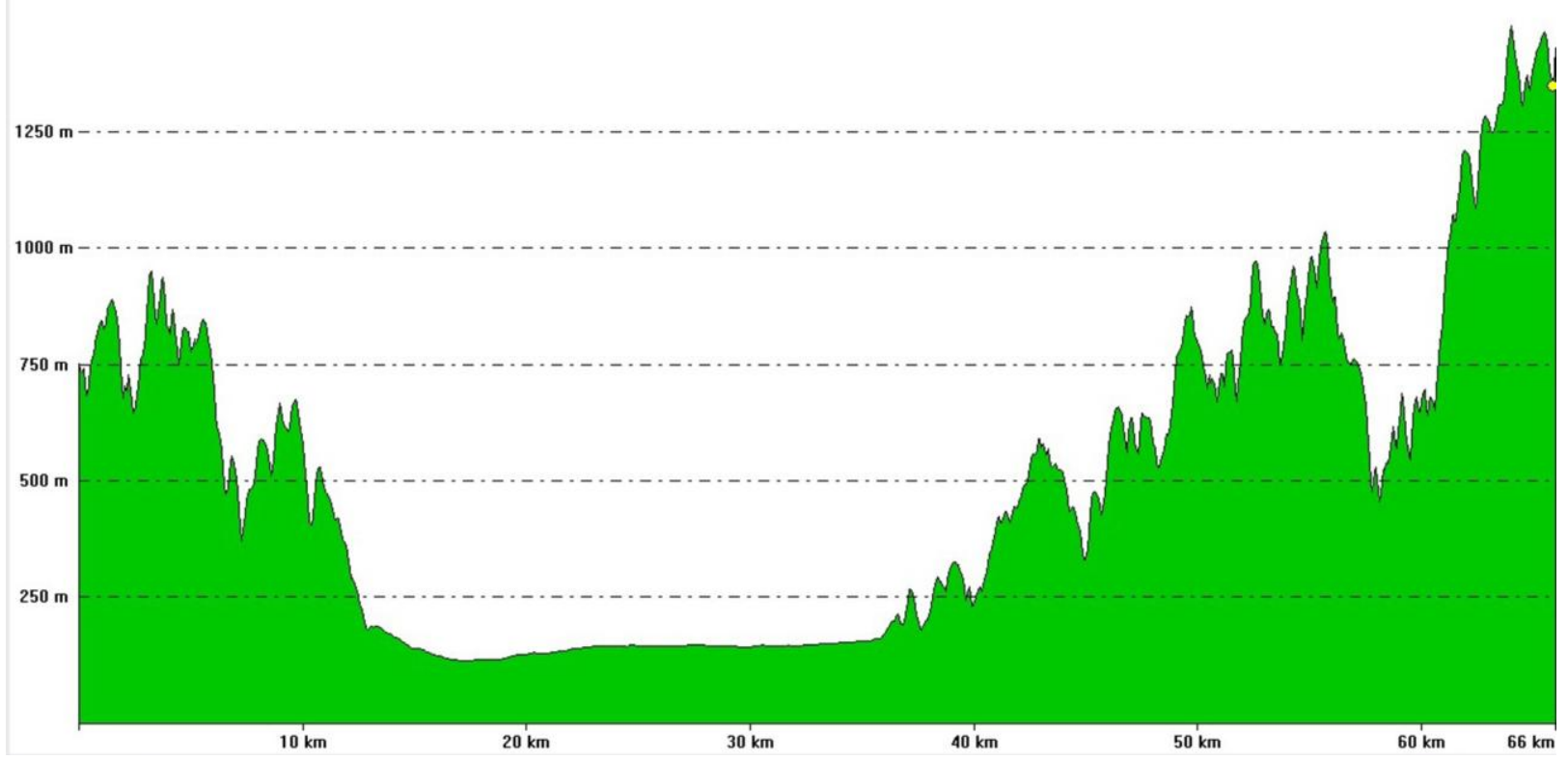

Figure 3. West to East cross-section of the Melen Basin

Slika 3. Presek od zapada prema istoku basena Melen

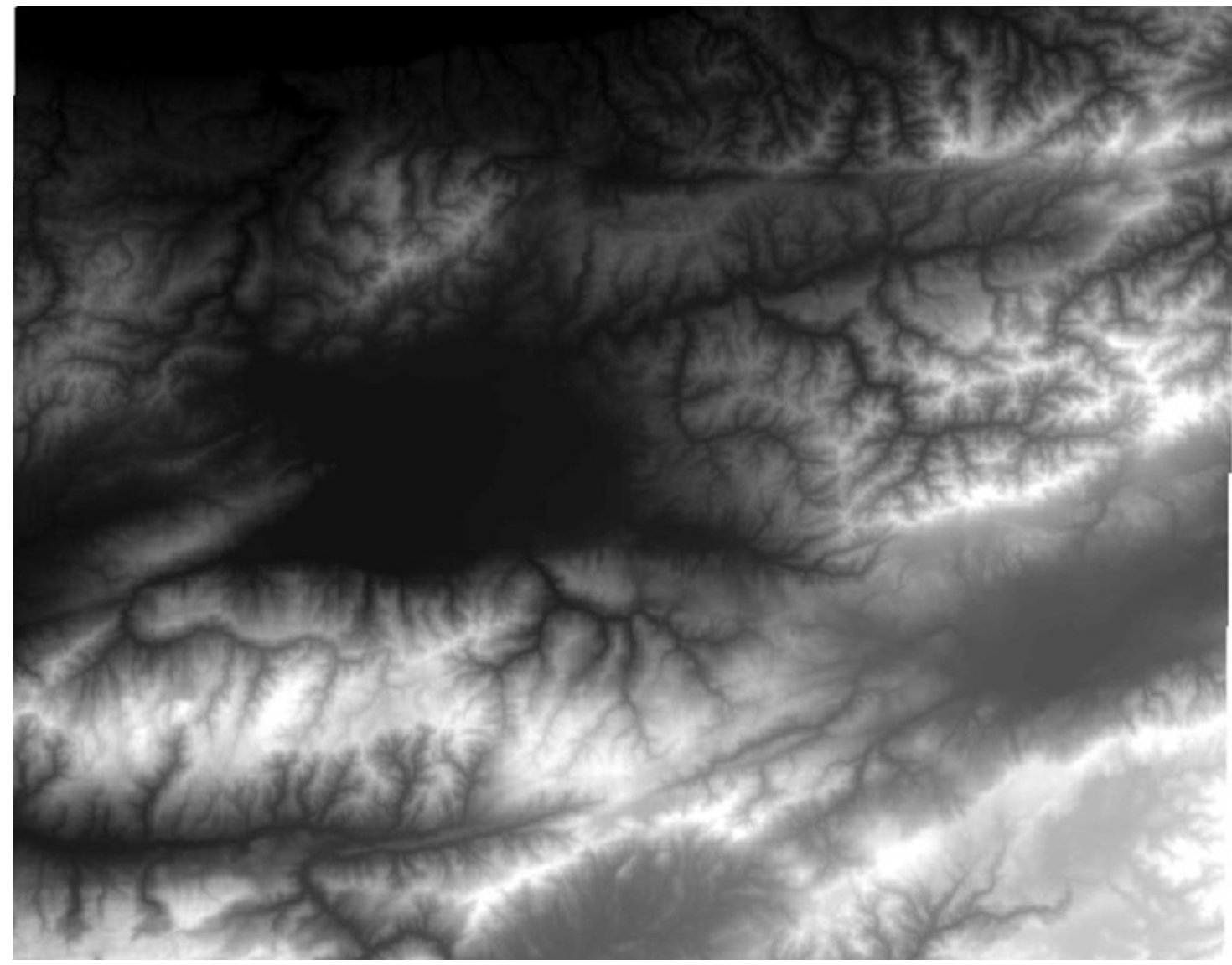

Figure 4. Ten meters grid spacing DEM converted in ESRI Grid format

Slika 4. Deset metara razmaka mreže DEM pretvorene u ESRI format mreže 
The DEM was used to delineate and analyze the drainage patterns of the basin. DEM derived parameters such as slope gradient, terrain pitch, and stream network feature such as channel pitch, width, and length. SWAT Model uses DEM for the calculation of the elevation statistics (See Table 1).

Table 1. Elevation statistics of the whole basin and subbasins

Tabela 1. Statistika nadmorske visine celog sliva i podslivova

\begin{tabular}{|c|c|c|c|c|c|c|c|c|c|c|c|}
\hline & \multicolumn{11}{|c|}{ Elevation report for the basin } \\
\hline & \multicolumn{11}{|c|}{ Statistics: All elevations reported in meters } \\
\hline & $\begin{array}{l}\text { Melen } \\
\text { Basin }\end{array}$ & $\begin{array}{c}\text { Subb. } \\
\# 1\end{array}$ & $\begin{array}{c}\text { Subb. } \\
\# 2\end{array}$ & $\begin{array}{c}\text { Subb. } \\
\text { \# } 3\end{array}$ & $\begin{array}{l}\text { Subb. } \\
\text { \# } 4\end{array}$ & $\begin{array}{l}\text { Subb. } \\
\text { \#5 }\end{array}$ & $\begin{array}{c}\text { Subb. } \\
\text { \# } 6\end{array}$ & $\begin{array}{c}\text { Subb. } \\
\# 7\end{array}$ & $\begin{array}{c}\text { Subb. } \\
\text { \# } 8\end{array}$ & \begin{tabular}{|c|} 
Subb. \\
$\# 9$
\end{tabular} & $\begin{array}{c}\text { Subb. } \\
\# 10\end{array}$ \\
\hline $\begin{array}{l}\text { Min. } \\
\text { Elevation }\end{array}$ & 5.0 & 5.0 & 256.0 & 256.0 & 130.0 & 256.0 & 256.0 & 115.0 & 130.0 & 115.0 & 115.0 \\
\hline $\begin{array}{l}\text { Max. } \\
\text { Elevation }\end{array}$ & 1953.0 & 1168.0 & 1656.0 & 950.0 & 1163.0 & 1953.0 & 1387.0 & 495.0 & 1580.0 & 1719.0 & 1830.0 \\
\hline $\begin{array}{l}\text { Mean. } \\
\text { Elevation }\end{array}$ & 651.0 & 331.2 & 772.3 & 545.0 & 340.7 & 1040.2 & 700.4 & 137.8 & 462.9 & 891.6 & 928.9 \\
\hline $\begin{array}{l}\text { Std. } \\
\text { Deviation }\end{array}$ & 424.5 & 218.2 & 282.6 & 156.4 & 189.7 & 306.9 & 206.9 & 47.6 & 298.8 & 457.4 & 460.4 \\
\hline
\end{tabular}

\subsection{Basin delineation}

This basin is divided into separate sub-basins to demonstrate the spatial variation in the catchment. SWAT works on a subbasin basis, and the interface delineates the basin into subbasins based on topographic information. The Melen Basin was the delineated basis on a DEM produced by digitizing topographic map sheets at a resolution of 10 meters $\times 10$ meters as well as by changing the existing vector maps. Creating DEM was imported into the Arcview grid format with appropriate projection (UTM - Zone $36 \mathrm{~N}$ WGS84 Datum).
Streams approximate the scale and number of the subbasin. Although a higher number of subbasins have spatial stability, they require more knowledge preparation and can also contribute to significant spatial variation. Therefore, a precise definition of the threshold is vital to show the optimal spatial variability of the catchment area. The delineated stream network discretized the basin into ten sub-basins. As a form file, the mask is prepared for the process of delineation of the basin (see Fig. 5). The methodology of the basin delineation and delineated Melen Basin is shown in Fig. 6 and 7, respectively.

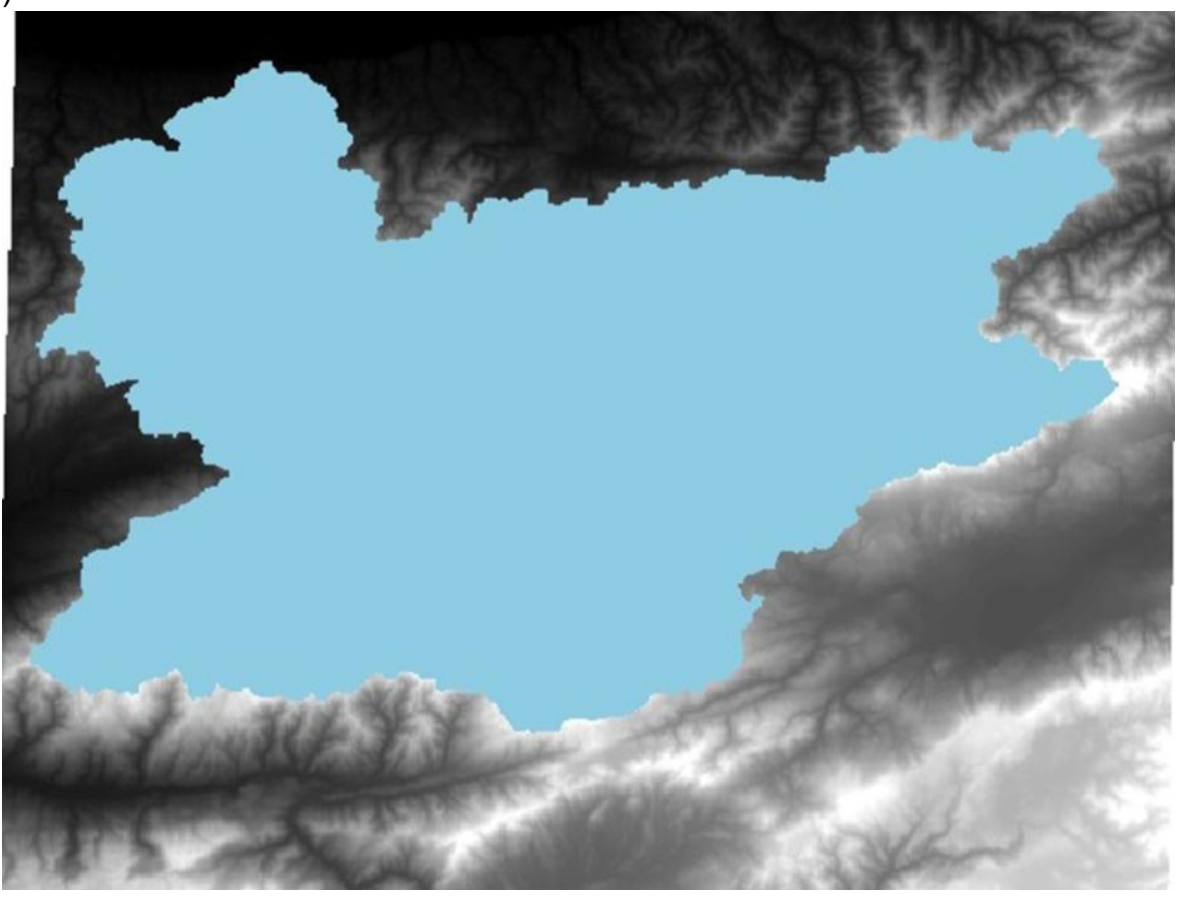

Figure 5. MASK of the Melen Basin for subbasin creation Slika 5. MASKA bazena Melen za stvaranje podbazena 
Digital elevation model (DEM)

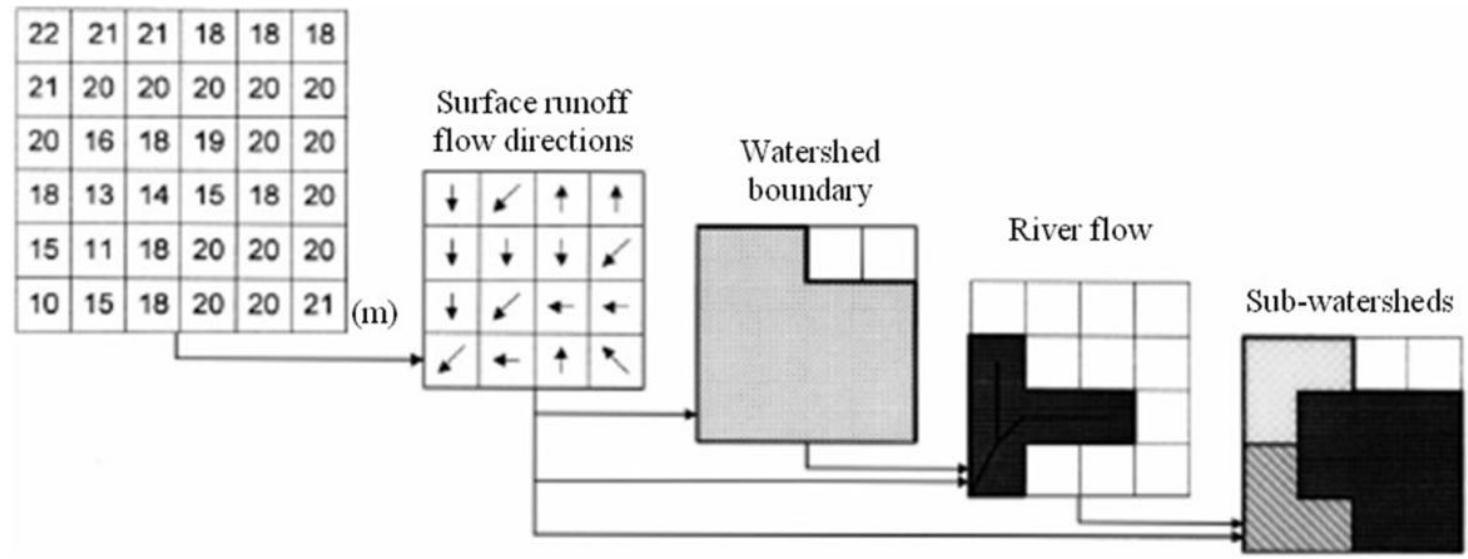

Figure 6. Delineation and determination of drainage basin using the Digital Elevation Model [34]

Slika 6. Razgraničenje i određivanje drenažnog bazena pomoću digitalnog elevacijskog modela [34]

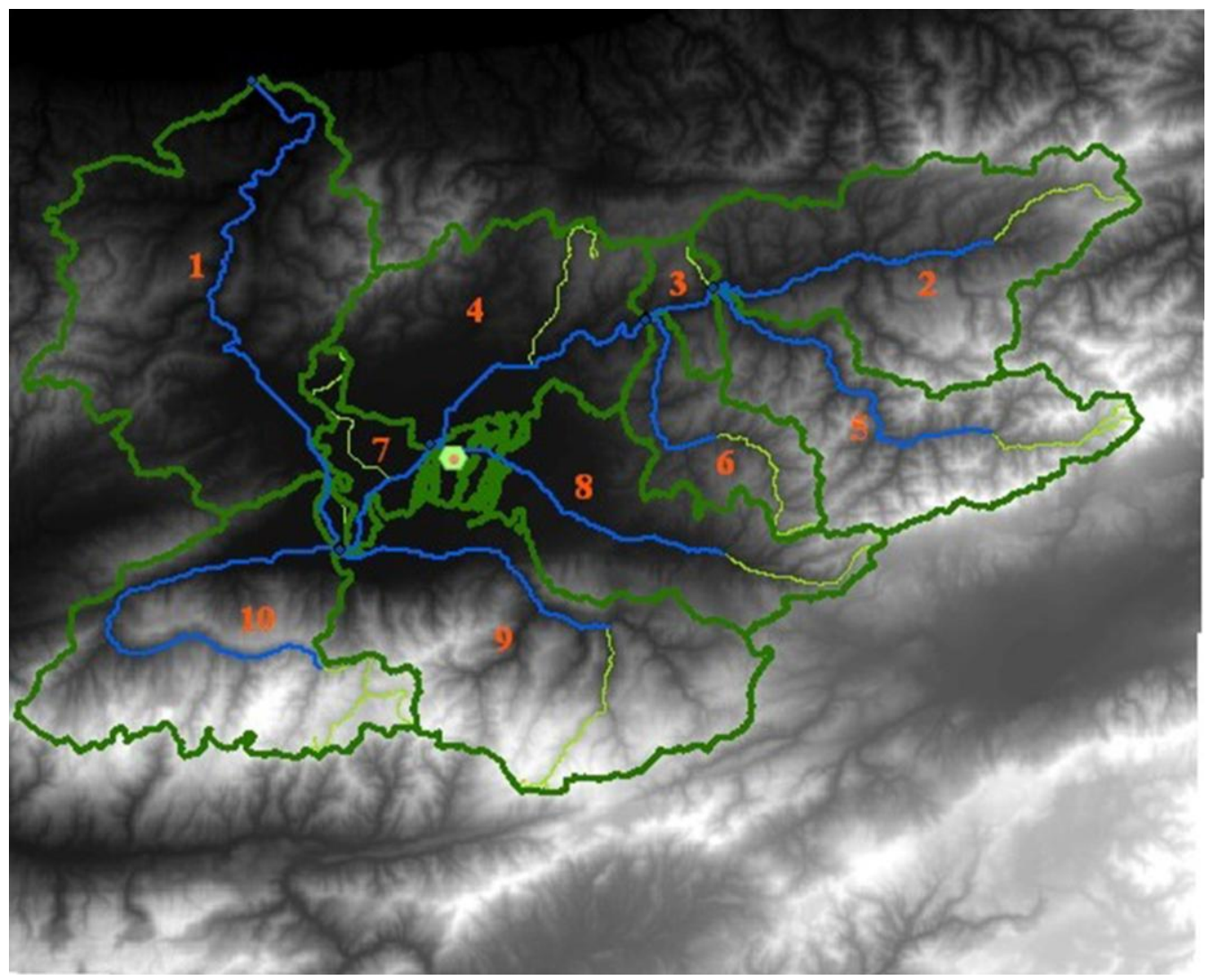

Figure 7. Subbasins and rivers of the Melen Basin

Slika 7. Podbazeni i reke Melenskog basena

While a soil classification map is necessary for the Hydrologic Response Units (HRUs) characterization, SWAT Model also requires many other physical and chemical soil characteristics data such as hydraulic conductivity, bulk density, texture, soil N \& $P$ content. SWAT Model allows the user to decide whether or not to use HRUs in the modeling application. In case HRUs are not used, the interface uses the dominant land use and soil characteristics for the entire subbasin, which ignores the spatial variability by lumping together the subbasin processes. See Fig. 8 and 9 for the created land use and slope grids. 


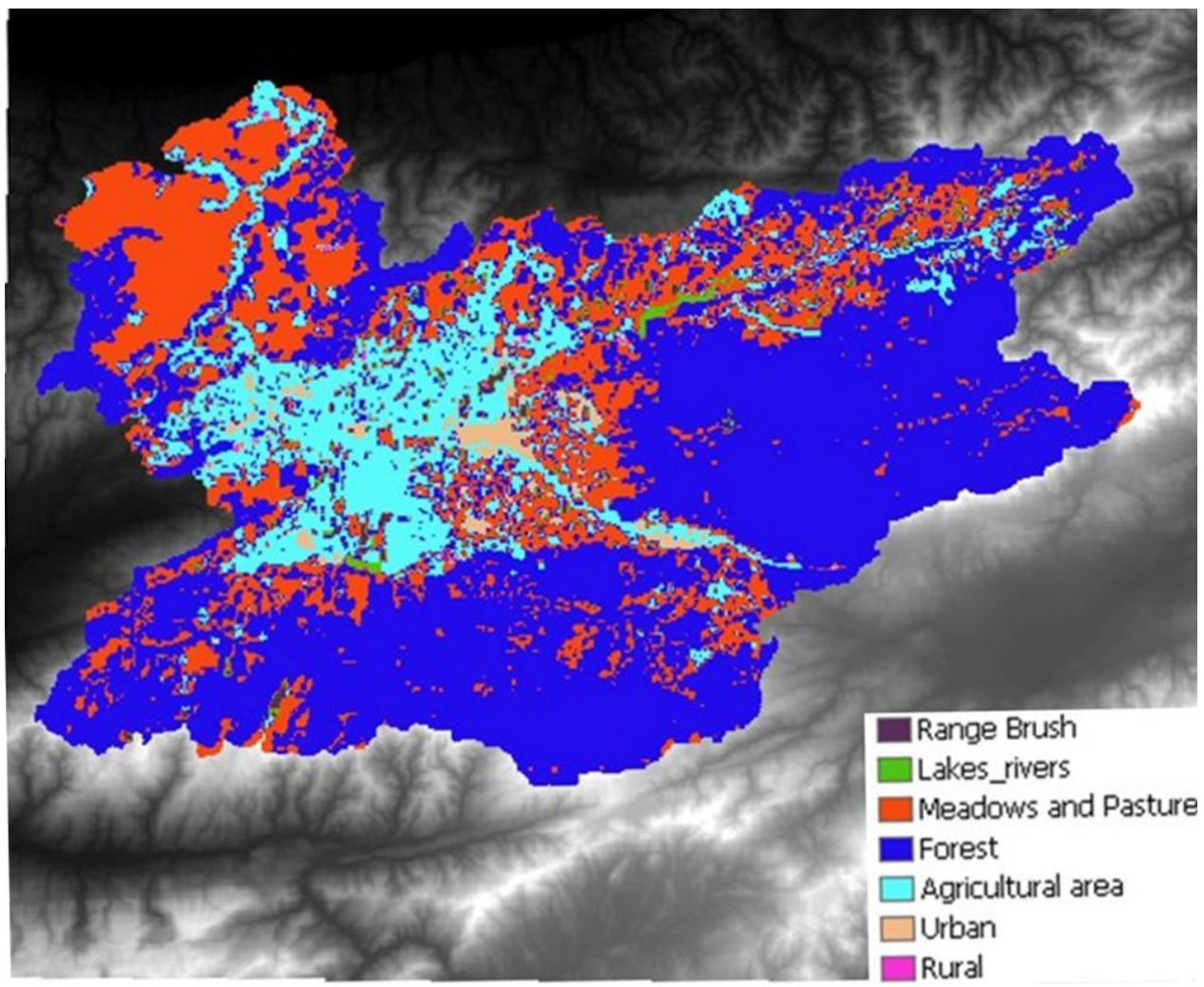

Figure 8. Land Use grids for the Melen Basin

Slika 8. Mreže za korišćenje zemljišta za sliv Melen

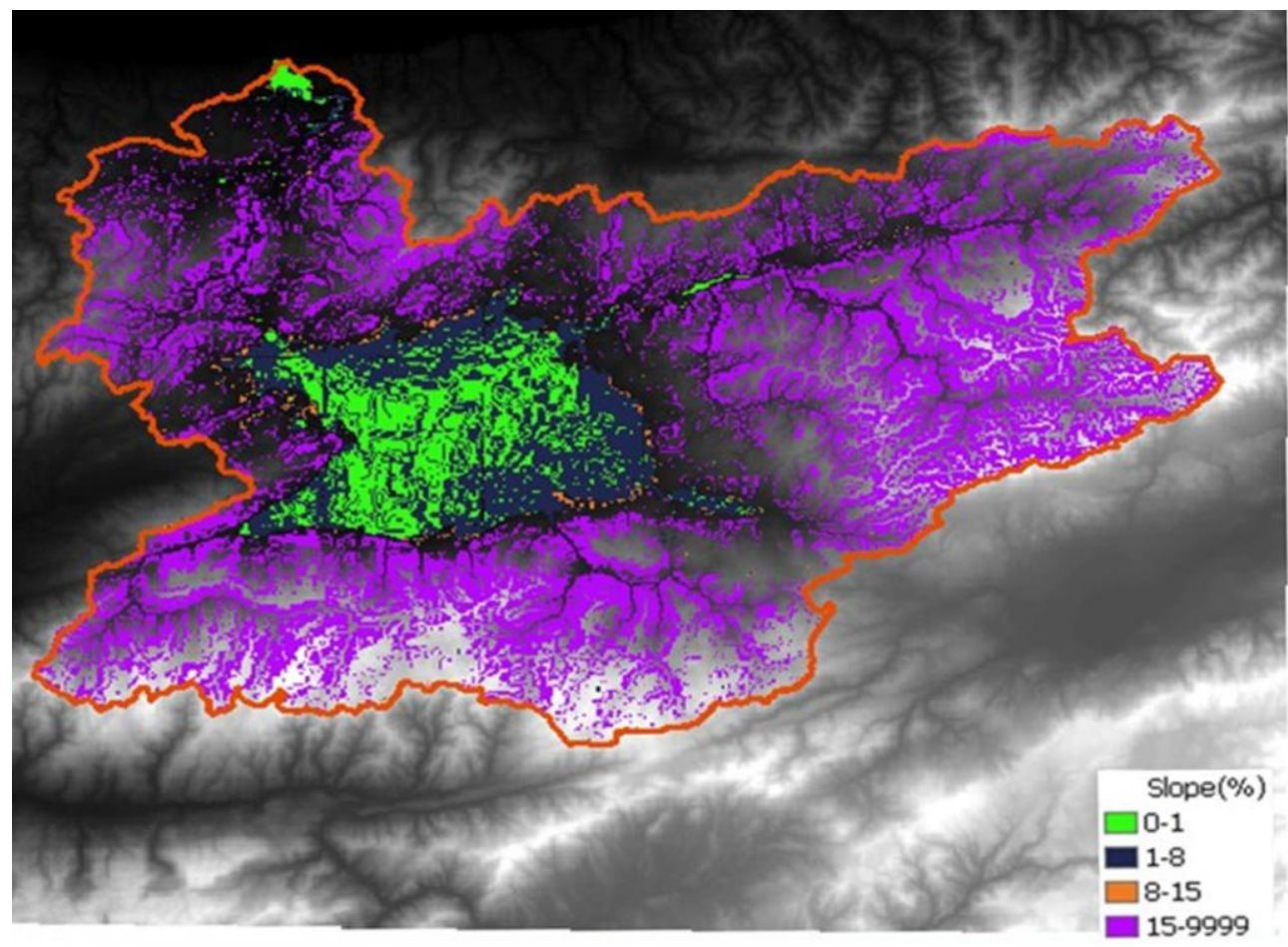

Figure 9. Land Slope grids for the Melen Basin

Slika 9. Kopnene mreže za sliv Melen 


\subsection{Soil classification of the Melen River Basin}

The soil of the Melen Basin, except for Duzce Plain, can be defined as natural sloping, calcareous soils (23E and 23F), and medium to the substantial body with organic matter-rich soils. Soils are formed in the calcareous parent material and have a 35 to $50 \%$ lime rate, mainly as a silty body - clay structure. Basin soils are $50-90 \mathrm{~cm}$ deep. Roughly broken land soil has a slope higher than $45 \%$, and it exists predominantly in Duzce. Brown forest soil's primary substance is hard limestone or marl. The mineral type of soil is usually illite clay. For all soil types, the $A B C$ horizon sequence is seen $(A$ : surface horizon, rich in an organic matter; B: Lime, found high base saturation (35-60\%), minerals and clay accumulation is high; C: The primary material (clay-type illite)). The main materials' content is rich in potassium. Alluvial lands are shown in Fig.10 as 1A, 2A, 10D; they are fertile and rich in minerals. Water-holding capacity is functional, and porosity is high. Fig. 10 is a portion of the soil classification map that shows the area covered by the Melen Basin [35].

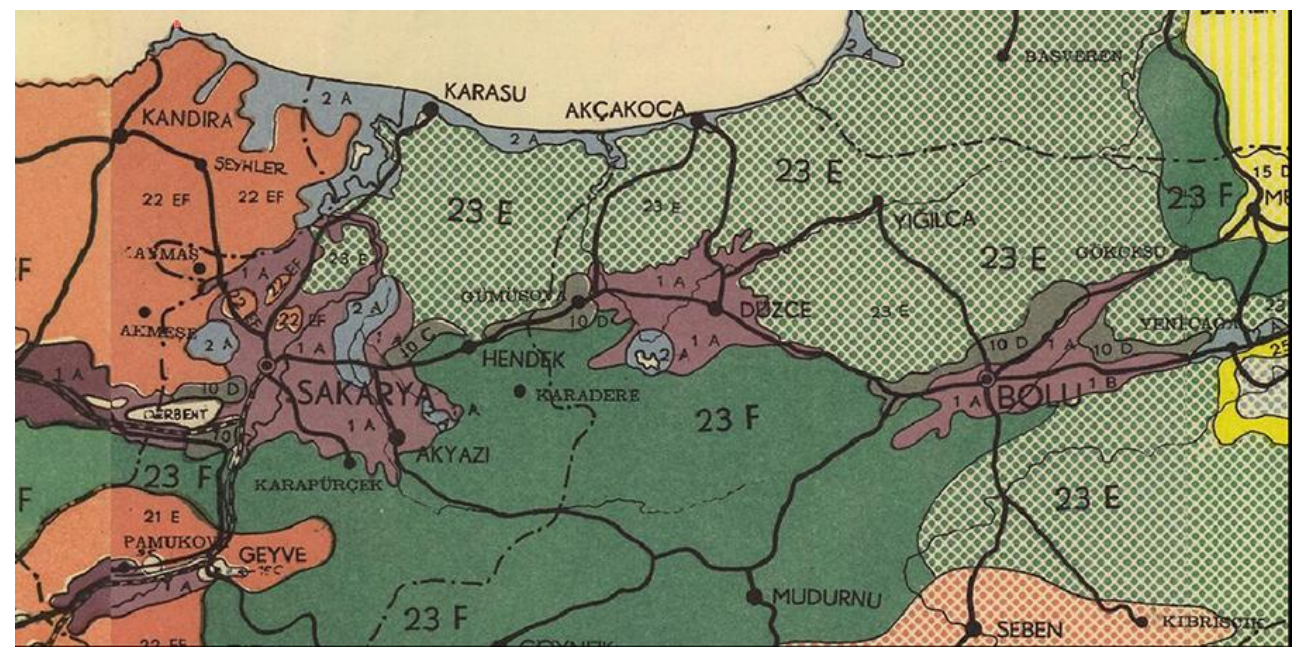

Figure 10. Soil classification map for the Melen Basin [35]

Slika 10. Mapa klasifikacije tla za sliv Melena [35]

\subsubsection{Soil orders}

The soil order in the region of the basin was described as follows, according to several citations, including ESBN [36], Eswaran et al. [37], Oakes [35], Onalp [38], Polat [39], and Soil Survey Staff [40].

- Rough mountainous land (in the Brown Forest soil zone), slope (> 45\%) at the south of the basin - Inceptisols.

- Rough broken land (Brown Forest soil material), slope (> 45\%) at the north of the basin - Alfisols.

- Alluvial and youthful soils from Alluvium, level $(0-1 \%)$ at the mid of the basin, and the Melen estuary area - Entisols.

- The hydromorphic soils, level $(0-1 \%)$ at the mid of the basin - Entisols.

- Lithosolic Rendzina soils, sharply sloping (8 $15 \%)$ at the west of the basin - Mollisols.

Rendzina is a moist, semi-arid, brown earth grassland formed over the parent calcareous soil. Inceptisols or Mollisols can fall within the rendzinas order. The prepared soil classification grids are illustrated in Fig. 11.

\subsubsection{Soil hydrologic groups}

Group A is the type of soils of sand, loamy sand, or sandy loam. Its form of soil has reduced drainage potential and a high degree of infiltration, even though adequately watered. Group B is loam or silt loam; in case thoroughly damp, it has a modest penetration rate. Sandy clay loam is Group $C$ soils. They consist of particles that hinder the downward flow of the water due to their relatively slim to fine-grain composition, if deeply saturated. This type of soil has reduced absorption rates. Group D soils are the clay, sandy clay, silty clay, clay-loam, and silty clay loam.

\subsubsection{Soil texture}

The silt-clay-sand ratios and the soil texture of the basin have been established through personal correspondence with Polat [39] regarding his Ph.D. thesis experiments. The soil layer's unique texture was described using the Soil Texture Triangle. The land use category is as relevant as soil classification in terms of nutrient export. Table 2 and Table 3 show land use categories for Melen Basin. 


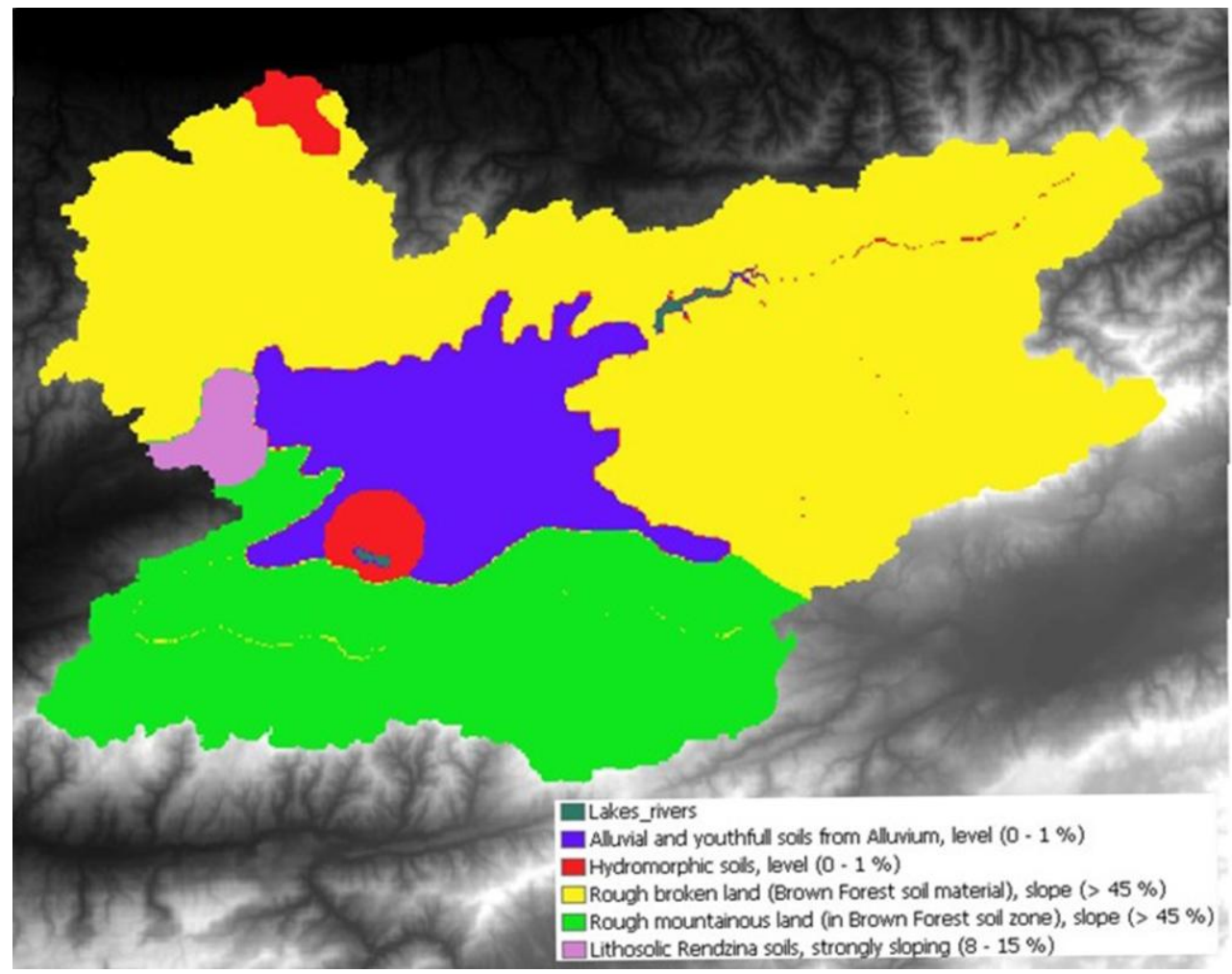

Figure 11. Melen Basin soil classification grids

Slika 11. Rešetke za klasifikaciju tla u slivu Melen

Table 2. Land use categories for the Melen Basin

Tabela 2. Kategorije korišćenja zemljišta za sliv Melen

\begin{tabular}{|l|c|c|c|}
\hline Whole basin - 10 subbasins & Area in ha & Area in acres & \% Water Area \\
\hline Range-Brush --> RNGB & 348.037 & 860.0168 & 0.15 \\
\hline Meadow Bromegrass --> BROM & 3132.333 & 7740.1515 & 1.31 \\
\hline Water --> WATR & 1460.8 & 3609.7098 & 21.46 \\
\hline HAZELNUT --> HZNT & 51379.28 & 126960.77 & 9.2 \\
\hline Pasture --> PAST & 22019.69 & 54411.757 & 51.25 \\
\hline Forest-Mixed --> FRST & 122728.8 & 303269.05 & 2.91 \\
\hline Corn --> CORN & 6978.57 & 17244.395 & 2.04 \\
\hline Durum Wheat --> DWHT & 4884.999 & 12071.077 & 0.29 \\
\hline Potato --> POTA & 697.857 & 1724.4395 & 0.29 \\
\hline Sugarbeet --> SGBT & 697.857 & 1724.4395 & 0.29 \\
\hline Tobacco --> TOBC & 697.857 & 1724.4395 & 8.74 \\
\hline Hazelnut --> HZLN & 20935.71 & 51733.186 & 1.27 \\
\hline Residential-High Density --> URHD & 3036.83 & 7504.1588 & 0.19 \\
\hline Residential-Low Density --> URLD & 455.57 & 1125.7362 & 10.66 \\
\hline Whole Basin & Area in ha & Area in acres & $\%$ Water Area \\
\hline Meadows Brush and Pasture & 25500.06 & 63011.93 & 0.61 \\
\hline Water & 1460.80 & 3609.71 & 36.02 \\
\hline Agricultural & 86272.13 & 213182.75 & 51.25 \\
\hline Forest & 122728.80 & 303269.05 & 1.46 \\
\hline Residential & 3492.40 & 8629.90 & 100 \\
\hline Total & 239454.19 & 591703.33 & \\
\hline
\end{tabular}


Table 3. Land use categories for subbasins

Tabla 3. Kategorije korišćenja zemljišta za podslivove

\begin{tabular}{|c|c|c|c|c|}
\hline Subbasin 1: & Area in ha & Area in acres & $\%$ Water Area & $\%$ Subb. Area \\
\hline Meadows Brush and Pasture & 7820.70 & 19325.34 & 3.27 & 16.43 \\
\hline Water & 130.96 & 323.61 & 0.05 & 0.28 \\
\hline Agricultural & 26959.37 & 66617.96 & 11.26 & 56.64 \\
\hline Forest & 12045.45 & 29764.50 & 5.03 & 25.30 \\
\hline Residential & 502.82 & 1242.49 & 0.21 & 1.06 \\
\hline Total & 47459.30 & 117273.90 & 19.82 & 100 \\
\hline Subbasin 2: & Area in ha & Area in acres & $\%$ Water Area & $\%$ Subb. Area \\
\hline Meadows Brush and Pasture & 3564.08 & 8807.01 & 1.48 & 11.67 \\
\hline Water & 198.23 & 489.84 & 0.08 & 0.65 \\
\hline Agricultural & 10367.52 & 25618.67 & 4.34 & 33.96 \\
\hline Forest & 16353.70 & 40410.81 & 6.83 & 53.57 \\
\hline Residential & 21.41 & 52.50 & 0.01 & 0.07 \\
\hline Total & 30504.94 & 75378.83 & 12.74 & 100 \\
\hline Subbasin 3: & Area in ha & Area in acres & $\%$ Water Area & $\%$ Subb. Area \\
\hline Meadows Brush and Pasture & 591.27 & 1461.05 & 0.25 & 15.85 \\
\hline Water & 224.73 & 555.32 & 0.09 & 6.03 \\
\hline Agricultural & 1530.86 & 3782.84 & 0.64 & 41.07 \\
\hline Forest & 1373.71 & 3394.51 & 0.57 & 36.84 \\
\hline Residential & 4.42 & 10.92 & 0.00 & 0.12 \\
\hline Total & 3724.99 & 9204.64 & 1.55 & 100 \\
\hline Subbasin 4: & Area in ha & Area in acres & $\%$ Water Area & $\%$ Subb. Area \\
\hline Meadows Brush and Pasture & 3963.93 & 9795.07 & 1.66 & 15.50 \\
\hline Water & 156.88 & 387.66 & 0.07 & 0.61 \\
\hline Agricultural & 74956.30 & 37427.27 & 6.32 & 59.23 \\
\hline Forest & 5528.17 & 13660.39 & 2.31 & 21.62 \\
\hline Residential & 703.79 & 1739.10 & 0.30 & 2.76 \\
\hline Total & 85309.07 & 63009.48 & 10.66 & 100 \\
\hline Subbasin 5: & Area in ha & Area in acres & $\%$ Water Area & $\%$ Subb. Area \\
\hline Meadows Brush and Pasture & 780.84 & 1929.46 & 0.33 & 3.30 \\
\hline Water & 116.32 & 287.43 & 0.05 & 0.49 \\
\hline Agricultural & 1962.60 & 4849.68 & 0.82 & 8.31 \\
\hline Forest & 20753.26 & 51282.34 & 8.67 & 87.77 \\
\hline Residential & 18.24 & 45.07 & 0.01 & 0.08 \\
\hline Total & 23631.26 & 58393.98 & 9.88 & 100 \\
\hline
\end{tabular}


Table 3 (Continued). Land use categories for subbasins

Tabela 3 (nastavak). Kategorije korišćenja zemljišta za podslivove

\begin{tabular}{|c|c|c|c|c|}
\hline Subbasin 6: & Area in ha & Area in acres & $\%$ Water Area & $\%$ Subb. Area \\
\hline Meadows Brush and Pasture & 283.34 & 700.14 & 0.11 & 2.61 \\
\hline Water & 155.71 & 384.77 & 0.07 & 1.44 \\
\hline Agricultural & 520.24 & 1285.54 & 0.22 & 4.80 \\
\hline Forest & 9880.05 & 24414.10 & 4.13 & 91.15 \\
\hline Total & 10839.34 & 26784.55 & 4.53 & 100 \\
\hline Subbasin 7: & Area in ha & Area in acres & $\%$ Water Area & $\%$ Subb. Area \\
\hline Meadows Brush and Pasture & 515.47 & 1273.76 & 0.21 & 9.23 \\
\hline Water & 30.09 & 74.35 & 0.01 & 0.54 \\
\hline Agricultural & 4580.78 & 11319.33 & 1.91 & 82.00 \\
\hline Forest & 311.60 & 769.98 & 0.13 & 5.58 \\
\hline Residential & 148.10 & 365.96 & 0.06 & 2.65 \\
\hline Total & 5586.04 & 13803.38 & 2.32 & 100 \\
\hline Subbasin 8: & Area in ha & Area in acres & $\%$ Water Area & $\%$ Subb. Area \\
\hline Meadows Brush and Pasture & 2787.73 & 6888.61 & 1.17 & 11.49 \\
\hline Water & 63.49 & 156.89 & 0.03 & 0.26 \\
\hline Agricultural & 9270.92 & 22908.92 & 3.88 & 38.23 \\
\hline Forest & 10469.57 & 25870.83 & 4.37 & 43.16 \\
\hline Residential & 1661.23 & 4104.98 & 0.69 & 6.85 \\
\hline Total & 24252.94 & 59930.23 & 10.14 & 100 \\
\hline Subbasin 9: & Area in ha & Area in acres & $\%$ Water Area & $\%$ Subb. Area \\
\hline Meadows Brush and Pasture & 2314.08 & 5718.20 & 0.96 & 6.23 \\
\hline Water & 260.17 & 642.89 & 0.11 & 0.70 \\
\hline Agricultural & 7766.66 & 19191.81 & 3.23 & 20.90 \\
\hline Forest & 26480.21 & 65433.92 & 11.06 & 71.27 \\
\hline Residential & 251.91 & 622.48 & 0.11 & 0.68 \\
\hline Total & 37073.03 & 91609.31 & 15.47 & 100 \\
\hline Subbasin 10: & Area in ha & Area in acres & $\%$ Water Area & $\%$ Subb. Area \\
\hline Meadows Brush and Pasture & 2878.63 & 7113.25 & 1.21 & 9.29 \\
\hline Water & 124.22 & 306.95 & 0.05 & 0.40 \\
\hline Agricultural & 8166.87 & 20180.74 & 3.41 & 26.33 \\
\hline Forest & 19533.10 & 48267.27 & 8.16 & 63.04 \\
\hline Residential & 180.48 & 445.98 & 0.07 & 0.58 \\
\hline Total & 30883.30 & 76314.18 & 12.90 & 100 \\
\hline
\end{tabular}

Since the basin area has a steep slope, and clayey and sandy soil structure, parallel terraces, grade stabilization, strip and contour cropping, constructed wetlands are appropriate BMPs. Besides, to protect agricultural areas from the excess nutrients transported from fields of meadows and pastures where cattle graze, stream fencing, and rotational grazing BMPs can be used. Melen Basin is a region that includes industrial, agricultural, and domestic areas. It is an important 
transit route with intercity transportation lines and highways. So, buffer filter strips BMP can be effectively used to protect against nutrients that can be transported by runoff from residential areas and highways.

\section{CONCLUSION}

After determining the soil type and land-use patterns of Melen Basin agricultural lands, it is possible to make a clear decision on the applicable BMPs. In this sense, this study is also expected to serve as an example for other agricultural basins of Turkey and the world. Turkey faced the threat of desertification and drought. Before it is too late, measures must be taken with correct and long-term land planning. The territory of Turkey is a high-risk group in terms of desertification. Before it is too late, measures should be taken with correct and long-term land planning. Desertification affects arid regions all over the world, hinders the development of economies, and causes impoverishment of the population in large areas, thus negatively affecting the natural environment and all living creatures in it.

Turkey is due to the climatic and topographical characteristics of the soil against erosion with precision, and incorrect due to human activities are under the threat of desertification. The only way to face the danger of desertification, which directly threatens the lives of about 1 billion people in the world, and to cope with this danger, is the ability of countries to take practical actions in cooperation and to use their ability to act together. Efforts should be made to protect, develop, and increase vegetation cover to reduce and prevent the effects of desertification.

The public, non-governmental organizations, and all relevant segments of the society have significant responsibilities in matters such as correct irrigation techniques, proper cultivation of the land, raising awareness, and training of farmers. When the upper part of the soil is lost, the soil becomes increasingly inefficient. It is necessary to use chemical fertilizers continuously to increase production. Naturally, it has severe damages to the soil.

Pasture improvement activities will be useful in preventing erosion. Since these areas are private property, the government should encourage erosion control efforts. Pesticides used in agricultural applications cause desertification and destruction of living things in the soil. The areas with the highest risk of desertification have low precipitation; It is the Central, Eastern, and Southeastern Anatolia Region. There is also a danger of desertification in agricultural lands in the
Aegean Region. The Central Anatolia Region has a large water deficit and has a high potential in terms of agricultural production. What needs to be done in this region is to grow durable products that require less water instead of producing plants that require excessive water. It is also necessary to implement more economical irrigation methods.

Turkey is one of the countries most adversely affected by climate change; rainfall is expected to decrease by 25 percent by 2050 . In this case, it means a reduction of 25 percent of Turkey's current water supply. Turkey is not a country which is rich in the presence of water, but rather one of the countries suffering from water stress. It will be one of the countries suffering from water scarcity due to population increase and a decrease in precipitation. Therefore, it is necessary to use water very economically.

Fighting against desertification should be based on correct and long-term land planning and protection of water resources and agricultural areas. Agricultural best management practices such as terracing, afforestation, and wind barriers should be carried out in areas suitable for erosion.

Global climate change is expected in Turkey, together with the changes made in areas of agricultural patterns and agriculture. It is essential to know which regions will no longer be agricultural areas and which regions will be more suitable for agriculture and to plan as soon as possible.

Turkey shows that erosion and landslides in the geographic region of the insidious advance. Soils are transported from the topography of the land through erosion in the slightest rainfall due to its rugged structure. In the face of this insidious event, soil maps should be revealed as soon as possible with scientific methods. Soil is a creature that lives with its organic matter and the water it contains. If the soil cannot hold or store water, sudden floods occur. This situation will be minimized when we protect the soil.

\section{REFERENCES}

[1] A.Erturk, M.Gurel, E.Varol, A.Ekdal, M.Baloch, T.Dikerler, D.Z.Seker, A.Tanik (2007) Analysis and Modelling of Land-Based Nutrient Pollution by Watershed Models Coupled with GIS: A Case Study from Turkey, Water Science \& Technology, 55(3), 115-122.

[2] V.Novotny, H.Olem (1994) Water quality: Prevention, identification, and management of diffuse pollution, Van Nostrand Reinhold, New York.

[3] W.F.Ritter, A.Shirmohammadi (2001) Agricultural Nonpoint Source Pollution: Watershed Management and Hydrology, CRC Press LC, Boca Raton. 
[4] N.S.Rao, Z.M.Easton, E.M.Schneiderman, M.S.Zion, D.R.Lee, T.S.Steenhuis (2009) Modeling watershed-scale effectiveness of agricultural best management practices to reduce phosphorus loading, Journal of Environmental Management, 90(3), 1385-1395.

[5] C.Santhi, R.Srinivasan, J.G.Arnold, J.R.Williams (2003) A modeling approach to evaluate the impacts of water quality management plans implemented in the Big Cypress Creek Watershed, Second conference on watershed management to meet emerging TMDL environmental regulations, Albuquerque, p.384-394.

[6] K.B.Vache, J.M.Eilers, M.V.Santelmann (2002) Water quality modeling of alternative agricultural scenarios in the U.S. corn belt, Journal of the American Water Resources Association, 38(3), 773-787.

[7] J.R.Williams, J.G.Arnold, R.Srinivasan (2000) The APEX model, BRC report no. 00-06, Texas Agricultural Experiment Station, Temple.

[8] Y.Yuan, S.M.Dabney, R.L.Bingner (2002) Cost effectiveness of agricultural BMPs for sediment reduction in the Mississippi Delta, Journal of Soil and Water Conservation, 57(5), 259-267.

[9] D.R.Edwards, T.C.Daniel, H.D.Scott, J.F.Murdoch, M.J.Habiger, H.M.Burkes (1996) Stream quality impacts of best management practices in a Northwestern Arkansas Basin, Journal of the American Water Resources Association, 32(3), 499-509.

[10] S.W.Park, S.Mostaghimi, R.A.Cooke, P.W. McClellan (1994) BMP impacts on watershed runoff, sediment, and nutrient yields, Journal of the American Water Resources Association, 30(6), 1011-1023.

[11] L.Kalin, M.M.Hantush (2003) Evaluation of sediment transport models and comparative application of two watershed models, National Risk Management Research Laboratory, the office of research and development, US EPA, Cincinnati.

[12] R.L.Blevins, W.W.Frye (1993) Conservation Tillage: An Ecological Approach to Soil Management, Advances in Agronomy, 51(1), 3378.

[13] T.A.Dillaha, B.B.Ross, S.Mostaghimi, C.D. Heatwole, V.O.Shanholtz (1988) Rainfall Simulation: A Tool for Best. Management Practice Education", Journal of Soil and Water Conservation, 43(4), 288-290.

[14] M.C.Smith, A.B.Bottcher, K.L.Campbell, D.L.Thomas (1991) Field Testing and Comparison of the PRZM and GLEAMS Models, Transactions of the American Society of Agricultural Engineers, 34(3), 838-847.

[15] J.Cho, S.Mostaghimi, M.S.Kang (2010) Development and Application of a Modeling Approach for Surface Water and Groundwater Interactions, Agricultural Water Management, 97(1), 123-130.

[16] C.D.Heatwole, S.Zacharias, S.Mostaghimi, T.A.Dillaha (1997) Movement of Field Applied at
Razine, Metolachlor, and Bromide in a Sandy Loam Soil, Transactions of the American Society of Agricultural Engineers, 40(5), 1267-1276.

[17] NRCS (2010) National Handbook of Conservation Practices, Washington.

[18] A.L.Heathwaite, P.Griffiths, R.J.Parkinson (1998) Nitrogen and Phosphorus in Runoff from Grassland with Buffer Strips Following Application of Fertilisers and Manures, Soil Use and Management, 14(1), 142-148.

[19] P.B.Parajuli, K.R.Mankin, P.L.Barnes (2008) Applicability of Targeting Vegetative Filter Strips to Abate Fecal Bacteria and Sediment Yield Using SWAT, Agricultural Water Management, 95(1), 1189-1200.

[20] S.L.Neitsch, J.G.Arnold, J.R.Kiniry, J.R.Williams (2005) Soil and water assessment tool: theoretical documentation, Agricultural Research Service, and Texas Agricultural Experiment Station, Temple.

[21] N.E.Haycock, G.Pinay (1993) Groundwater Nitrate Dynamics in Grass and Poplar Vegetated Riparian Buffer Strips During the Winter, Journal Environmental Quality, 22(2), 273-278.

[22] M.Sahu, R.R.Gu (2009) Modeling the Effects of Riparian Buffer Zone and Contour Strips on Stream Water Quality, Ecological Engineering, 35(1), 11671177.

[23] F.M.Brandi-Dohrn, R.P.Dick, S.M.Kauffman, D.D.Hemphill Jr., J.S.Selker (1997) Nitrate leaching under a cereal rye cover crop, Journal of Environmental Quality, 26(1), 181-188.

[24] B.J.Chambers, K.A.Smith, B.F.Pain (2000) Strategies to Encourage Better Use of Nitrogen in Animal Manures, Soil Use and Management, 16(1), 157-161.

[25] N.S.Campbell, B.J.D'Arcy, C.A.Frost, V.Novotny, A.L.Sansam (2004) Diffuse pollution: an Introduction to the problems and the solutions, IWA Publishing, London.

[26] J.Traba, F.M.Azcarate, B.Peco (2004) From What Depth Do Seeds Emerge? A soil Seed Bank Experiment with Mediterranean Grassland Species, Seed Science Research, 14(1), 297-303.

[27] J.L.Baker, H.P.Johnson (1983) Evaluating the Effectiveness of BMPs from Field Studies, in Agricultural Management and Water Quality, Schaller R. W. and Bailey G. W., eds., lowa State University Press, Ames, lowa, p.281-305.

[28] Q.Yang, F.R.Meng, Z.Zhao, T.L.Chow, G.Benoy, H.W. Rees, C.P.A.Bourque (2009) Assessing the Impacts of Flow Diversion Terraces on Stream Water and Sediment Yields at a Watershed Level Using SWAT Model, Agriculture, Ecosystems, and Environment, 132(1), 23-31.

[29] A.R.Jarrett (2000) Water Management, 2nd edition, Kendall Hunt Publishing Co. Inc., Dubuque.

[30] C.T.Haan, B.J.Barkfield, J.C.Hayes (1994) Design Hydrology and Sedimentology for Small Catchments, Academic Press, New York. 
[31] J.M.Chambers, T.J.Wrigley, A.J.McComb (1993) The Potential Use of Wetlands to Reduce Phosphorus Export from Agricultural Catchments, Fertilizer Research, 36(1), 157-164.

[32] P.M.Haygarth, P.J.Chapman, S.C.Jarvis, R.V. Smith (1998) Phosphorus Budgets for Two Contrasting Farming Systems in the UK, Soil Use and Management, 14(1), 160-167.

[33] J.Zobrist, P.Reichert (2006) Bayesian Estimation of Export Coefficients from Diffuse and Point Sources in Swiss Watersheds, Journal of Hydrology, 329(12), 207-223.

[34] Ş.T.A.Aslan, K.S.Gundogdu, A.O.Demir (2004) Sayısal Yükseklik Modelinden Yararlanılarak Bazı Havza Karakteristiklerinin Belirlenmesi: Bursa Karacabey İnkaya Göleti Havzası Örneği", Uludağ Üniversitesi Ziraat Fakültesi Dergisi, 18(1), 167180.

[35] H.Oakes (1954) The Soils of Turkey, Food and Agriculture Organization of the United Nations (FAO), Ankara.
[36] ESBN (2005) Soil Atlas of Europe, European Soil Bureau Network European Commission, Office for Official Publications of the European Communities, L-2995 Luxembourg.

[37] H.Eswaran, T.Rice, R.Ahrens, B.A.Stewart (2003) Soil Classification - A Global Desk Reference, CRC Press, Boca Raton.

[38] A.Onalp (1982) Insaat Muhendislerine Geoteknik Bilgisi Cilt 1, Yayin No: 187, Karadeniz Teknik Universitesi, Trabzon.

[39] A.H.Polat (2000) Duzce Ovasi Sulama Isletmesinde Optimum Su Kullanim Modelinin Belirlenmesi Uzerine Bir Arastirma, Ph.D. Thesis, Gazi University.

[40] Soil Survey Staff (1999) Soil Taxonomy: A Basic System of Soil Classification for Making and Interpreting Soil Surveys, 2nd edition, US Department of Agriculture Soil Conservation Service, Washington.

\title{
IZVOD
}

\section{STUDIJA SLUČAJA UREĐENJA I KORIŠĆENJA ZEMLJIŠTA ZA ODREĐIVANJE NAČINA UPRAVLJANJA ZEMLJIŠTEM KOJI SE MOŽE PRIMENITI U POLJOPRIVREDNOJ PRAKSI ZA SPREČAVANJE EROZIJE I GUBITKA PLODNOG ZEMLJIŠTA}

\begin{abstract}
Reka Buiuk Melen u slivu Melen zadovoljava Istanbulske potrebe za pijaćom vodom. Zaštita bazena od zagađenja hranjivim sastojcima, takođe, je vitalna u ovom pogledu. Ova studija usredsređena je na najbolju moguću praksu upravljanja (BMP) u bazenu Melen kako bi se smanjio izvoz hranljivih sastojaka iz poljoprivrednih područja. Regija koja obuhvata industrijske, poljoprivredne i stambene zone je sliv Melena. U Turskoj postoji prognoza globalnih klimatskih promena, a naučnici i guverneri moraju znati koja područja više nisu poljoprivredne zone, a koja će biti prikladnija za poljoprivredu. Teritorija Turske je područje visokog rizika od dezertifikacije. U slivu Melen, vrsta zemljišta i svojstva korišćenja zemljišta utvrđeni su i mapirani pomoću GIS-a i Alata za procenu tla i vode (SWAT). Filterske trake puferskog BMP-a mogu se efikasno koristiti za zaštitu hranljivih sastojaka, koji se mogu odneti iz stambenih naselja i autoputeva. Regija u slivu je strma, a njene glinene i peskovite strukture tla idealne su za paralelne terase, stabilizaciju stepena, trakastu i konturnu kultivaciju. Ako tlo ne može da zadrži ili uskladišti vodu, zemljište može pretrpeti iznenadne poplave, što dovodi do erozije produktivnog površinskog sloja tla. Kada zaštitimo zemlju, ovo stanje se smanjuje. Kartiranje vrste zemljišta i upotrebe zemljišta trebalo bi da bude napravljeno što je pre moguće za preostale Turske basene naučnim metodama. Iz ovog razloga ovo istraživanje ima za cilj ilustraciju istraživanja na drugim poljoprivrednim basenima u Turskoj i svetu.
\end{abstract}

Ključne reči: Najbolje poljoprivredne prakse upravljanja, erozija, upotreba zemljišta, sliv Melen, hranljive materije, vrsta tla.

\section{Naučni rad}

Rad primljen: 20. 08. 2020.

Rad prihvaćen: 23. 09. 2020.

Rad je dostupan na sajtu: www.idk.org.rs/casopis

(C) 2020 Authors. Published by Engineering Society for Corrosion. This article is an open access article distributed under the terms and conditions of the Creative Commons Attribution 4.0 International license (https://creativecommons.org/licenses/by/4.0/) 